\title{
CHOSEN ASPECTS OF DEFINING TECHNICAL WEAR OF BUILDINGS
}

\author{
Małgorzata Konarzewska ${ }^{1}$ and Artur Konarzewski ${ }^{2}$ \\ Institute of Structural Engineering, Division of Construction Engineering and Management, \\ Poznan University of Technology, Piotrowo 5, 6-965 Poznan, Poland \\ E-mail:1 konarzewska@poczta.onet.pl; 2artur.konarzewski@ikb.poznan.pl
}

Received 12 December 2005; accepted 15 September 2006

\begin{abstract}
The article discusses the problem of defining borderline values of technical wear of a building and/or its components. Formulas and methods of defining wear have been highlighted, and an example has been presented, where the calculations were made according to proportionality formulas: Ross and Unger, Romstorfen and Eytelwein. While analysing results, some differences have been pointed out in the assessment of the degree of wear, depending on the time lapse and selection of a calculation formula. Selecting an inappropriate calculation procedure (depending on the focus on an element), and incorrect manner of defining technical life span of an element or a whole building leads to serious errors. The justifiability of the above statement has been proved in the summary, where a comparison of element use, according to different calculation formulas, has been presented in a graphic form.
\end{abstract}

Keywords: technical wear, wear of buildings, defining technical condition of buildings, methods of defining technical condition, technical condition of elements, age of the element, formula of proportionality, formula of Ross and Unger, formula of Romstorfen, formula of Eytelwein, time flow method.

\section{Introduction}

The degree of technical wear of buildings is usually determined for a number of purposes, mainly for the purpose of planning repairs (scheduled by the person in charge of managing the property), or in order to estimate its value (this is done by a professional real estate assessor). The knowledge about technical wear is very useful to the architect during the design phase, so that proper design solutions and materials can be selected at the right time, and the efficiency analysis can be performed (especially regarding commercially oriented properties). Such knowledge will

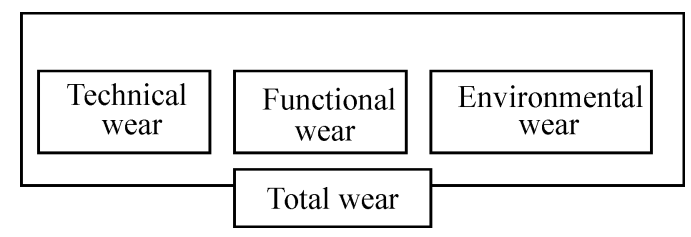

Fig 1. Wears of buildings also be useful to the contractor and an architect supervising practical implementation of his or her design on site.

Wear is understood as the decrease in value of real estate resulting from its technical wear (physical), functional (use), and environmental wear. Basing on those factors, total wear is defined, being (in view of current principles [1]) the biggest value out of those mentioned above (see Fig 1).

\section{Methods of defining technical condition of buildings and their elements}

Among methods used to identify technical wear, the major two are visual and time flow methods.

\subsection{The visual method}

Among visual methods, there are those which define wear of a building as a whole on the basis of the degree of wear of its specific self-contained construction elements (such as foundation, main walls, partition walls, floors and ceilings, rafters, roof surface, etc.), as well as those where the degree of technical wear of the building is defined bas- 
ing on the degree of wear of groups of elements of which the building consists. The formula used to calculate wear is as follows [2-4]:

$$
S_{z t}=\sum_{i=1}^{n} \frac{U e_{i} \times S z t e_{i}}{100},
$$

where: $S_{z t}$ - weighted mean degree of technical wear; $U e_{i}-$ percentage of share of value of $i$-th element $n$ the con of the whole building; Szte ${ }_{i}$ - degree of technical wear of $i$-th selfcontained construction element; $n$ - a number of self-contained construction elements; $i$ - another element.

Within the framework of the visual method, during the examination of a building, the degree of wear of its various elements is assessed, while the assessor looks at their technical condition and life span. For a number of reasons, such assessment requires extensive knowledge and experience, also due to the subjective view at the condition a part of the building may be in, and that is why certain discrepancies can come up in the results between experts involved in valuation. There is also a danger of formulating a wrong diagnosis when this method is employed. Namely, within the framework of the formula quoted above (1), various degrees of wear of particular elements, in view of their share in the cost of the whole building, add up as a result being a weighted mean of the degree of wear of the whole building. Such an approach results in a specific "blurring" of the influence of wear of one element on other elements. Indeed, there are elements which, though playing a relatively small part in its general cost, will have a strong influence on its overall technical condition, for example foundations, main walls, floors or ceilings. It is possible to imagine a house where, for instance, foundations and main load bearing walls are in bad technical condition, while the remaining elements are in very good condition. If the above formula is used, the degree of technical wear of the building may seem small, while in reality, the building will require extensive repairs. It is true to say that if technical wear of specific elements of a building does not differ dramatically, the resulting assessment of wear in the whole building will be credible and precise.

\subsection{The time flow method}

It is also possible to identify technical wear of a building using the time flow method, which requires the knowledge of the period of time of usage, as well as the envisaged period of life of the building. The envisaged life span of the building depends, though, on the level of care invested in the building itself thus, from the practical viewpoint, providing only one value is not recommended. It is necessary to define a time frame (time limits) which may enable the assessor to select a value adequate to the level of care in a given element or building [2-5].
The division into different levels of care regarding a building (even into 4 groups) existed in Poland as early as in the first decades of the twentieth century.

The mentioned levels are reflected by formulas quoted below, which identify the degrees of technical wear of a building:

- The linear formula of proportionality is used when little care is given to the maintenance of the building:

$$
S_{z t}=\frac{t}{T} 100[\%]
$$

where: $S_{z t}$ - degree of technical wear of the building; $t$ - period of the usage of the building [in years]; $T$ - envisaged life span of the building [in years];

- Ross and Unger formula is used when average care is taken with regard to the maintenance of the building (i.e. when current and major repairs are done on time):

$$
S_{z t}=\frac{t(t+T)}{2 T^{2}} 100[\%]
$$

- Romstorfen formula is used when above average care is taken with regard to the maintenance of the building:

$$
S_{z t}=\frac{t(2 t+T)}{3 T^{2}} 100[\%]
$$

- Ross and Eytelwein formula is used when extreme care is taken with regard to the maintenance of the building:

$$
S_{z t}=\frac{t^{2}}{T^{2}} 100[\%] .
$$

The example below illustrates the problem of defining the life span of a building.

\section{Example}

Element: timber frame walls, life span: $25-40$ years. The span of the life of the element may nearly double, so it becomes essential how much care is taken with respect to the prolongation of technical life of the element through proper insulation and maintenance of the element.

\section{Case 1}

The element is 20 years old, the building is poorly maintained, the technical wear will be illustrated by the following (2) proportionality formula. In this case the envisaged life span of the building (an element of) should be assumed to be 25 years (see Fig 2). 


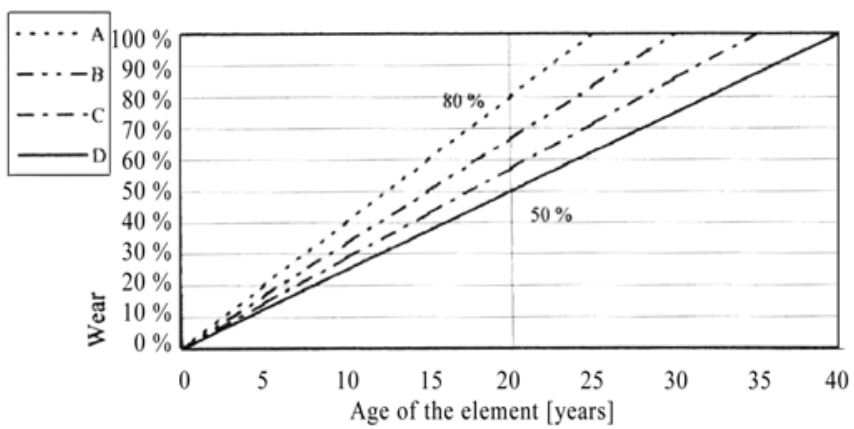

Fig 2. Wear graph according to the formula of proportionality

The graph above illustrates the difference in the degree of wear, depending on the envisaged total life span of the element:

line A - element usage with assumed total life span of 25 years;

line B - element usage with assumed total life span of 30 years;

line $\mathrm{C}$ - element usage with assumed total life span of 35 years;

line D - element usage with assumed total life span of 40 years.

\section{Case 2}

The element is 20 years old, with average good technical maintenance of the building, technical wear is illustrated in accordance with Ross tables or Unger formula, expressed by (3). In this case, the envisaged life span of the building (an element of) should be assumed to be 30 years (see Fig 3).

The above graph illustrates the difference in the degree of wear depending on the envisaged total life span of an element, line markings on the graph are as above.

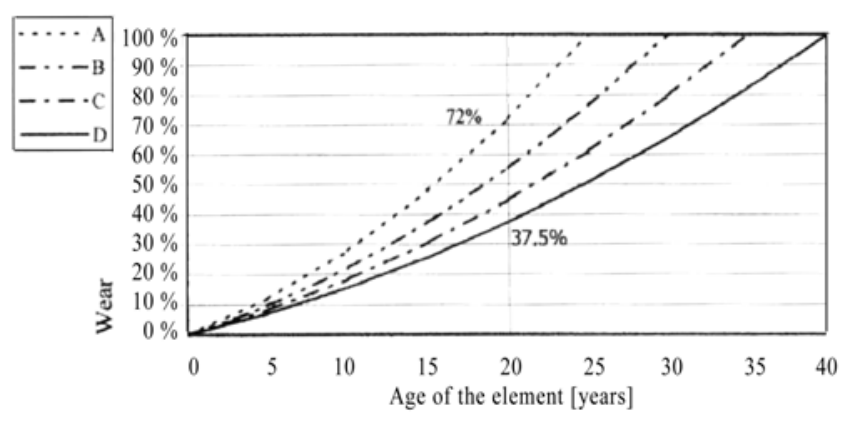

Fig 3. Technical wear graph in accordance with Unger, Ross

\section{Case 3}

The element is 20 years old, with above average technical maintenance of the building, technical wear is illustrated by Romstorfen formula, expressed by (4). In this case, the envisaged life span of the building (an element of ) should be assumed to be 35 years (see Fig 4).

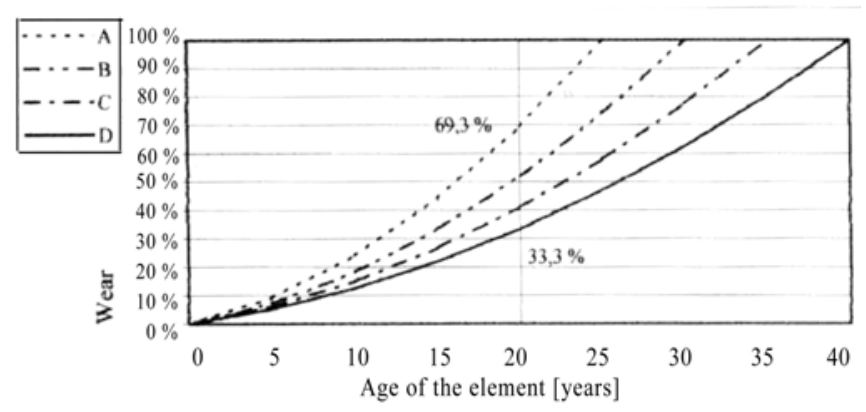

Fig 4. Technical wear graph in accordance with Romstorfen formula

The graph illustrates the difference in the degree of wear depending on the envisaged total life span of an element, line markings on the graph are as above.

\section{Case 4}

The element is 20 years old, with meticulous technical maintenance of the building, technical wear is illustrated by Eytelwein formula, expressed by (5). In this case, the envisaged life span of the building (an element of) should be assumed to be 40 years (see Fig 5).

The graph illustrates the difference in the degree of wear depending on the envisaged total life span of an element, line markings on the graph are as above.

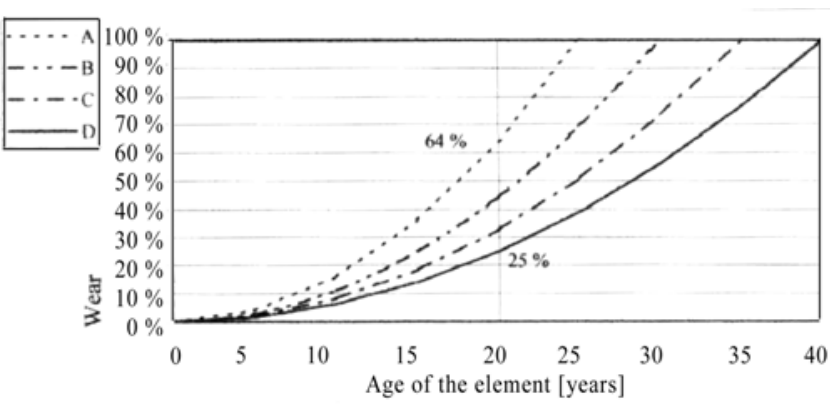

Fig 5. Technical wear graph in accordance with Eytelwein formula

\section{Analysis of the example and conclusions}

The above example illustrates how extreme the differences in identifying the degree of technical wear of an element may be, if its envisaged life span is undervalued or overvalued.

The difference between extreme cases may be even as much as $39 \%$ (Case 4 ), and in subsequent cases $(3,2$, and 1$)$ $36 \%, 34,5 \%$ and $30 \%$, respectively. Quite clearly, the values are not marginal.

Another, equally important aspect is the identification of the level of care and the maintenance quality of the building (or its element). In this situation, the differences in defining the degree of technical wear are in the range of $16-25 \%$. 
Fig 6 below compares the graphs of wear of an element with the envisaged total life span of 25 years, illustrated by all the formulas discussed in the paper:

A for F1 - technical wear illustrated by the proportionality formula;

A for F2 - technical wear illustrated by Unger, Ross formula;

A for F3 - technical wear illustrated by Romstorfen formula;

A for F4 - technical wear illustrated by Eytelwein formula.

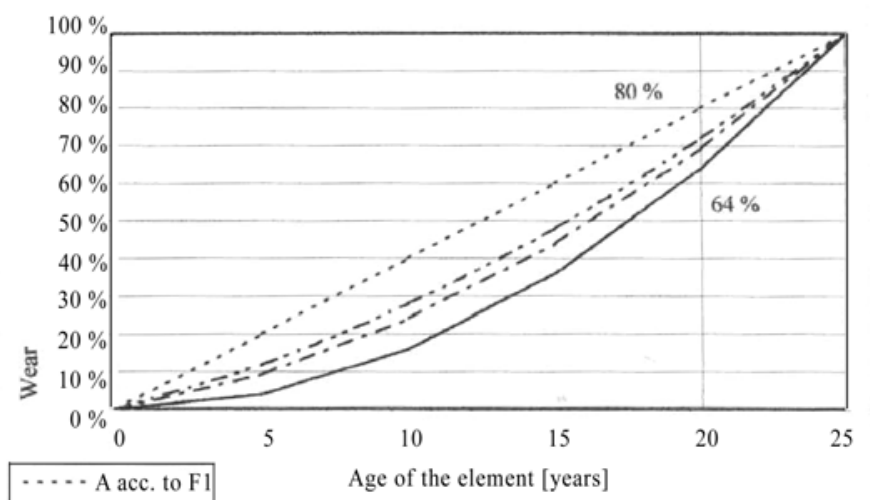

$-\cdots-$ A acc. to F2
$---A$ acc. to F3
$-A$ acc. to F4

Fig 6. Technical wear graph according to different formulas
The case of incorrect identification of the total life span of an element and, simultaneously, wrong assumption as to the level of care with respect to that element seems to be the least favourable case; then, the difference between extreme cases is $55 \%$.

\section{References}

1. Real estate valuers' professional standards (Standardy zawodowe rzeczoznawców maj'tkowych). Warszawa: PFSM, 2002, p. 1-4 (in Polish).

2. Baranowski, W. Technical wear in buildings and basic definitions in construction (Zużycie obiektów budowlanych oraz podstawowe nazewnictwo budowlane). Warszawa: WACETOB, 2000, p. 42-43 (in Polish).

3. Baranowski, W.; Cyran, M. Valuation and technical wear of real estate buildings (Wycena i zużycie nieruchomości zabudowanych). Warszawa: IDM, 2002, p. 26-33 (in Polish).

4. Winniczek, W. Valuation of buildings and structures (Wycena budynków i budowli). Warszawa: WACETOB, 1995, p. 2123 (in Polish).

5. Kucharska-Stasiak, E. Polish experience in real estate valuation between the World Wars (Doświadczenia polskie w zakresie wyceny nieruchomości w okresie międzywojennym). Poznan, 1992, p. 11-17 (in Polish).

\section{TECHNINIO PASTATŲ NUSIDE்VĖJIMO IVERTINIMO ASPEKTAI}

\section{Konarzewska, A. Konarzewski}

Santrauka

Straipsnyje diskutuojamos pastatų ar jų komponentų techninio nusidejvejjimo tikslumo įvertinimo problemos. Aprašyti nusidèvẻjimo Ł̇vertinimo metodai ir formulès, pateikti pavyzdžiai, kuriuose skaičiuota pagal proporcingumo, Rosso ir Ungurio, Romstorfeno ir Eytelweino formules. Tyrimai atskleide, jog atsižvelgiant ị pasirinktą laikotarpi ir skaičiavimo formules, gautos nusidejvejimo reikšmès skiriasi. Pasirinkus netinkamą elemento eksploatacijos trukmės skaičiavimo metoda, gaunamos nemažos paklaidos. Tai rodo i̇vairiu skaičiavimų metodų lyginamoji grafinè išraiška.

Reikšminiai žodžiai: techninis nusidèvèjimas, techninès pastatų būklès nustatymas, techninès būklès nustatymo metodai, techninė elementų būklè, elemento amžius, proporcingumo formulè, Ungerio ir Rosso formulè, Ramstorfeno formulè, Eytelweino formulè, senèjimą ivvertinantis metodas.

Malgorzata KONARZEWSKA. M. Sc., Ph D student at the Construction and Environmental Engineering Department. Poznan University of Technology, Institute of Structural Engineering, Division of Construction Engineering and Management. Master of Science (2003). Research interests: housing estate constructions wear, life cycles of a building, degree of technical wear.

Artur KONARZEWSKI. M. Sc., Lecturer. Poznan University of Technology, Institute of Structural Engineering, Division of Construction Engineering and Management. Master of Science (1998). Research interests: Real estate estimates, investment and construction process organisation, construction industry economics. 